\section{O-205 献腎移植77症例の免疫抑制療法と移植成績}

\section{藤田保健衛生大学 泌尿器科1)}

佐々木ひと美1) 星長 清隆1) 白木良一1) 内藤和彦1)

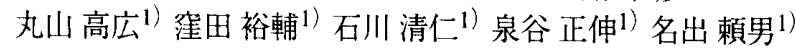
【目的】心停止ドナ一腎を用いた献腎移植の直後より少量のシク ロスポリン (CyA) と 3 剂または 2 剂を併用する免疫抑制を77例 に行い移植成績を検討した。対象】77例の腎移植時年齢は15才 60 才 (平均 40.5 㧘)、移植前の透析期間は平均 8 年 2 ケ、ドナーの 年齢は3才 69才 (平均46.3歳) であった。免疫抑制はCyA、メチ ルプレドニソロン（MP）、ALG、アザチオプリン（AZA）の4郕 を移植直後より開始し、腎機能の回復後にAZAをミゾリビン （MZ）に変更した。また10例ではCyA、MPおよびRS61443(MMF) の 3 戍を術後 6 ケ月間使用した。なお CyAは経口量として1日 4 $\mathrm{mg} / \mathrm{kg}$ から開始し、トラフ值がA T N 期間中は $100 \mathrm{ng} / \mathrm{ml}$ 以下、腎機 能の回復後には $150-250 \mathrm{ng} / \mathrm{ml}$ となるように調節した【結果と考察】 移植腎の温阻血時間は 1 分 $~ 52$ 分 (平均 10.3 分)、総阻血時間は 325分～2603分（平均1031分）で、術直後に利尿を認めたものは18 例のみで、59例では平均12.1日間の術後透析を要した。1例はド ナー由来のD I C 腎で術後 9 日目に移植㛑を摘出した。移植後 1 年、3 年、 5 年の患者生存率はそれぞれ $97.3 \% 、 95.9 \% 、 92.3 \%$ 、 移植後 1 年、 3 年、 5 年の腎生着率はそれぞれ $96.0 \% 、 94.6 \%$ 、 $85.4 \%$ で、我々が施行している少量のCyAを移植直後より使用し た免疫療法が心停止ドナ一腎を用いた献腎移植に有用であること が示唆された。

献腎移植 シクロスポリン 移植腎生着率

\section{O-207督移植患者における娃娠とその長期予後に
ついて}

\begin{abstract}
東京女子医大 泌尿器科 ${ }^{1)}$

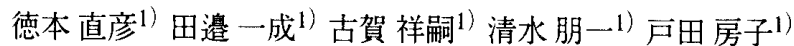

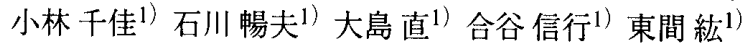

緒言: 今回われわれは妊娠後腎移植患者および移植腎の予後につ いて検討した。対象：1971より1998までに東京女子医大で腎移植 を行い姡娠出産した39例を対象とした。移植時平均年令は27.7才。 出産時平均年路は30.2才。39例中 34 例は生体腎, 5例は死体腎であ った。妊娠前の免疫抑制郕は、シクロスポリン使用が32例、夕ク ロリムス使用が1例、conventional regimenが5例であった。腎移植か ら妊娠までの平均期間は48.6r月、出産後平均経過観察期間は 106.1 个月であった。結果：(1) 娃娠結果：39例の腎移植患者で全53 回の娃娠であった。53娃娠中43娃娠(81.1\%)は出産し、10妊娠は流 產(自然流産4, 人工中絶6)であった。1例は双子出産したため44览 が誕生した。43妊娠のうち8例(18.6\%)は妊娠中毒症を合併した。 (2) 㚪娠後腎移植患者扩よび移植腎の予後：39例のうち1例か脳卒 中により死亡した(出産後9.2年)。39例のうち7例が graft lossとなっ たか、、姃娠出産後 3 年以内のgraft lossはなかった。その内訳は、慢 性拒絶反応4例、noncompliancee例、CYA腎毒性1例、死亡に伴う裚 失1例であった。生存率抢よび生着率は 10 年でそれぞれ $97.4 \%$,

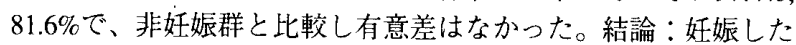
腎移植患者の約18\%にgraft lossを認めるものの腎移植患者および妊. 娠後の移植埥機能は長期的にみても良好であった。
\end{abstract}

腎移植 好娠 移植腎の予後
0-206 カルシヌリンインヒビター（CI）使用下に 成績と予後決定因子

\begin{abstract}
藤田保健衛生大学 泌尿器科1)
淮田裕輔1)星長清隆1) 白木 良一1) 平野真英1) 内藤和彦1)

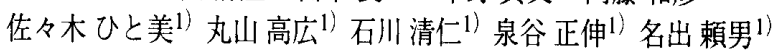
【目的】体内局所潅流冷却法を用い摘出された心停止ドナ一腎の 予後と腎生着率以影響を与える因子を解析する。【対象】当施設 で摘出した345腎の内、感染等の理由で使用できなかった33腎を除 き、CI使用下に多施設で移植された 312 腎の子後を調查し、予後影 響因子としてドナー年齢、温阻血時間 (WIT)、総阻血時間 (TIT)、 ドナー死因、レシピエント体重の各項目につき解析した。【結果】 ドナーとレシピエントの平均年齢はそれぞれ45.5歳、39.8歳であっ た。また、WITの平均は12.6分、TITの平均は13時間23分であった。 primary non-function を来したものは16腎 $(4.6 \%) て ゙ 、$ immediate functionを認めたものは46腎であった。残りの 234 腎はATNを来 したが平均11.3日で透析を離脱した。 Kaplan-Meier 法を用いた全体 の腎生着率は、1年 $84.4 \% 、 3$ 年 $74.4 \% 、 5$ 年 $68.1 \% 、 10$ 年 $54.8 \%$ であ った。各因子の内ドナー年齢では51歳以上群での生着率の有意な

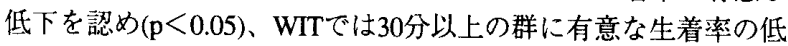
下を認めた $(\mathrm{p}<0.001)$ 。一方、TTTやドナー死因、レシピエント体 重等は生着率に影響を及ほさなかった。結論】体内局所潅流冷 却法を用い、心停止ドナ一腎を使用した献腎移植でも比較的良好 な生着率が得られた。また、ドナー年秢（51藏以上）、WIT（30分 以上）が生着率に影響を与えていた。
\end{abstract}

心停止ドナー 体内局所潅流泠却法 予後影響因子

\section{O-208 移植觜生検組轿におけるInterstitial Fibrosisの定量化の試み}

\begin{abstract}
社会保険中京病院 泌尿器科1）社会保険中京病院腎搰内科2） 岡崎市民病院 ${ }^{3)}$ 名古屋大学泌尿器科 4 )

古川 亨 ${ }^{1 ）}$ 絹川 常郎 ${ }^{1)}$ 田中 國晃 ${ }^{1)}$ 山本茂樹1) 杉山 敏 ${ }^{2)}$ 服部良平3) 山田伸4) 小野佳成 ${ }^{4)}$ 大島伸一4)

[目的]移植腎の慢性拒絶反応への進展を解明するために,移植腎 1 時 間生検組織の間質線維化をイメージ解析により定量化し，移植前 後の各因子との関係を検討した。[対象と方法] 1989年より1994年 までに社会保険中京病院で施行した献腎移植例 21 例を対象とし た。移植後の1時間生検組織のMasson's Trichrome染色標本光顕像 をデジタル画像化し，間質の線維化を示す青染部分の面積をカウ ントし，1視野全体の面積に占める割合を求め, 5 視野以上の值を平 均しIF値とした。[結果] IF值は平均6.7\%(1.3-14.9\%)であった。 Low IF群(IF $\leqq 7) 11$ 例とHigh IF群(IF $>7) 10$ 例の2群に分け，移植前後 の各因子との関倸を検討した。ドナー因子(年齢，性，死因)及び 阻血時間との間に有意差はなかったが，退院前・移植1年目の最 良血清クレアチニン值及び移植腎生着率は,Low IF群がHigh IF群に 比較して,有意に良好であった。[まとめ] 献腎移植後の1時間生検 像において，間質線維化を定量化(IF值)し，移植前後の各因子と 比較検討した。High IF群はLow IF群に比較して,移植後・1年後の Cr及び移植腎生着率は,有意に不良であった。本法は移植腎生検組 織の間質線維化の評価に有用であり，IF值は移植後の予後推測因 子となりうると考えられた。
\end{abstract}

献腎移植 間質線維化 慢性拒絶反応 